\title{
ANALYSIS OF Y BALANCE TEST AND DORSIFLEXION LUNGE TEST IN PROFESSIONAL AND AMATEUR SOCCER PLAYERS
}

\author{
ANÁLISE DO Y BALANCE TESTE DORSIFLEXION LUNGE TEST EM ATLETAS DE FUTEBOL PROFISSIONAIS \\ EAMADORES
}

Original Article

ARTIGO ORIGINAL

Artículo Original

\author{
ANÁLISIS DEL Y BALANCE TESTY DORSIFLEXION LUNGE TEST EN ATLETAS DE FÚTBOL \\ PROFESIONALES YAMATEURS
}

\section{Marcela Godoy Xixirry \\ (Physiotherapist) \\ Marcelo Riberto' \\ (Physiatrist) \\ Lucas Sartori Manoel' \\ (Physiotherapist)}

1. Universidade de São Paulo,

Faculdade de Medicina de Ribeirão Preto, Department of Biomechanics, Physical Medicine and Rehabilitation of the Locomotor System, Ribeirão Preto, SP, Brazil.

\section{Correspondence:}

Lucas Sartori Manoel

Rua Marques da Cruz, 1430, Monte

Alegre, Ribeirão Preto, SP, Brazil.

14051-150.

lucas.sartori.fisio@gmail.com

\begin{abstract}
Introduction: The ankle has the highest incidence of soccer injuries (17 to 20\% of injuries), which can cause personal and professional losses for the athlete. Ankle stability is due to a number of mechanisms, such as muscle control between agonists and antagonists, proprioception, balance, and muscle strength. If there are changes in any of these mechanisms, there is an increased risk of ankle injuries. Objective: The purpose of this study was to analyze the ankle function of amateur and professional soccer players in the preseason, using Y Balance Test (YBT) and Dorsiflexion Lunge Test (DLT), observing possible functional deficits in this sample, and subsequently analyzing the relationship of results between the functional tests in this population. Methods: A total of 107 soccer players were assessed, of whom 36 were amateur and 71 professional athletes. The volunteers initially underwent history taking, followed by a 5-minute warm-up on a stationary bicycle then the YBT and DLT functional tests. Results: There was no significant difference in the DLT between dominant and non-dominant limbs in amateur and professional athletes. There was also no significant difference in the YBT between dominant and non-dominant limbs of amateur athletes, but there was a significant difference between dominant and non-dominant limbs in professional athletes. There was no correlation between the tests when the dominant and non-dominant limbs of the sample were analyzed. Conclusion: The weak relationship between the functional tests indicates that both tests are recommended for athletes in clinical practice, since they serve as tools to assess different functional deficits. Level of Evidence III - Case-control study.
\end{abstract}

Keywords: Ankle; Physical functional performance; Soccer.

\section{RESUMO}

Introdução: Otornozelo apresenta a maior incidência de lesões no futebol (17 a 20\% das lesões), podendo causar prejuízos pessoais e profissionais para o atleta. A estabilidade do tornozelo deve-se a uma série de mecanismos, tais como controle muscular entre agonistas e antagonistas, propriocepção, equilibrio eforça muscular. Caso haja alterações em algum desses mecanismos, há maior risco de lesões no tornozelo. Objetivo: O objetivo do presente estudo consistia em analisar a função do tornozelo dos atletas de futebol amadores e profissionais, no período de pré-temporada, utilizando os testes Y Balance Test (YBT) e Dorsiflexion Lunge Test (DLT), observando possíveis déficits funcionais nessa amostra e, posteriormente, analisar a relação dos resultados entre os testes funcionais nessa população. Métodos: Foram avaliados 107 atletas de futebol, sendo 36 atletas amadores e 71 atletas profissionais. Os voluntários passaram por uma anamnese inicial seguida por um pré-aquecimento de cinco minutos em bicicleta ergométrica e pelos testes funcionais YBT e DLT. Resultados: Não houve diferença significativa no DLT entre os membros dominantes e não dominantes em atletas amadores e profissionais. Além disso, não houve diferença significativa no YBT entre os membros dominantes e não dominantes dos atletas amadores, entretanto, houve diferença significativa entre os membros dominantes e não dominantes dos atletas profissionais. Não houve correlação entre os testes quando analisados os membros dominantes e não dominantes da amostra. Conclusão: A baixa relação entre os testes funcionais indica que a realização de ambos érecomendada para atletas na prática clínica, sendo ferramentas de avaliação de déficits funcionais distintos. Nível de Evidência Ill; Estudo caso-controle.

Descritores: Tornozelo; Desempenho físico funcional; Futebol.

\section{RESUMEN}

Introducción: El tobillo presenta la mayor incidencia de lesiones en el fútbol (17 a 20\% de las lesiones), pudiendo ocasionar perjuicios personales y profesionales para el atleta. La estabilidad del tobillo se debe a una serie de mecanismos, tales como control muscular entre agonistas y antagonistas, propiocepción, equilibrio, y fuerza muscular. En caso que haya alteraciones en alguno de esos mecanismos, hay mayor riesgo de lesiones en el tobillo. El objetivo del presente estudio consistía en analizar la función del tobillo de atletas de fútbol, de las categorías amateury profesional, en el período de pretemporada, utilizando los tests Y Balance Test (YBT) y Dorsiflexion Lunge Test (DLT), observando posibles déficits funcionales en esa muestra y, posteriormente, analizar la relación de los resultados entre los tests funcionales en esa población. Métodos: Se evaluaron 107 atletas de fútbol, siendo 36 atletas amateurs y 71 atletas profesionales. Los voluntarios pasaron por una anamnesis inicial seguida por un precalentamiento de 5 minutos en bicicleta ergométrica y por los tests funcionales YBT y DLT. Resultados: No hubo diferencia significativa en el DLT 
entre los miembros dominantes y no dominantes en atletas amateurs y profesionales. Además, no hubo diferencia significativa en el YBT entre miembros dominantes y no dominantes de atletas amateurs, pero hubo diferencia significativa entre los miembros dominantes y no dominantes en atletas profesionales. No hubo correlación entre los tests cuando analizados los miembros dominantes y no dominantes de la muestra. Conclusión: La baja relación entre los tests funcionales indica que la realización de ambos es recomendada para atletas en la práctica clínica, siendo herramientas de evaluación de déficits funcionales distintos. Nivel de evidencia III; Estudio caso-control.

Descriptores: Tobillo; Rendimiento físico funcional; Fútbol.

\section{INTRODUCTION}

The ankle is the lower limb joint with the highest risk to injury in sports, particularly in soccer, ${ }^{1}$ where the represents 17 to $20 \%$ of total injuries in the sport. 2,3 Its stability requires several mechanisms and structures that minutely control the movement of that segment. Evaluation of ankle instability should consider multifactorial causes like the reduction of muscle strength of the lower limbs, delay in the contractile response time of the ankle stabilizing muscles, proprioceptive changes or changes in postural control. ${ }^{4-6}$ In addition to bone, capsular and ligamentous structures, ankle stability depends especially on dynamic control mechanisms, such as neuromuscular control, proprioception and strength. Thus, the pre-season evaluation of such mechanisms aiming at ankle stability is thought to be relevant in the prediction and prevention of injuries.

Functional tests are clinical tools widely used in the assessment of lower limb function, providing qualitative and quantitative data on proprioception, strength, range of motion, and balance. Many of the tests are commonly cited in the literature, presenting good reproducibility and intraobserver reliability. ${ }^{7,8}$ The Y Balance Test (YBT) is a simpler version of the Star Excursion Balance Test, in which the lower limb excursion is performed in only 3 directions to assess static balance and dynamic postural control. 9,10 The Dorsiflexion Lunge Test (DLT) is a simple and practical way of measuring the range of motion of the ankle joint. ${ }^{9}$ Both are sensitive to lower limb dysfunctions, and can be used as tools to measure the athlete's ability to return to the sport after injury, or even prevent future injury. Such tests are widely used in the evaluation of the athlete, since these tests are low cost, easy to perform and reliable in the detection of risks of musculoskeletal injuries in athletes. ${ }^{11}$

Ankle range of motion (ROM) is one of the biomechanical conditions necessary for YBT and can be assessed with DLT, in which ankle dorsiflexion widely is measured in a weigh bearing dynamic task. Several studies have proved a relationship between YBT and DLT. 10,12,13 However, weak correlation measures require further comprobatory studies. Also, it is not clear if the amount of train can be associated with modifications in these tests.

\section{OBJECTIVE}

To compare the ankle functional assesment tests between amateur athletes and soccer professionals in the preseason period.

\section{METHOD}

\section{Sample:}

This study was approved by the the internal review board of Hospital das Clínicas de Ribeirão Preto (approval protocol 16094/2014) and the participants signed an Informed Consent when they were first contacted for the study and checked for the inclusion criteria. This is a single-center cross-sectional study. One hundred and seven soccer athletes were evaluated in the age group from 18 to 45 years of age, of which 36 amateur athletes were linked to Academic Athletic Associations of the University of São Paulo - USP, campus of Ribeirão Preto, and 71 professional athletes from clubs in the region of Ribeirão Preto, during the pre-season of the Paulista 2016 Championship. The criteria for inclusion of the group of amateur athletes were: 1) to practice at least one hour of daily training, up to 3 times a week; 2) to be associated to one of the Academic Athletic Associations at the campus of Ribeirão Preto of the University of São Paulo. For professional athletes, the inclusion criteria were: 1 ) to train at least 3 to 5 hours daily, 5 times a week 2) to be professionally enrolled in clubs linked to the Brazilian Football Confederation (CBF). Exclusion criteria were: 1) to bear recent or active musculoskeletal injuries at the time of evaluation, manifested by pain, swallowing, limitation to sport activity or reduction of performance, or recent postoperative state; 2 ) refuse to sign the informed consent form.

After recruitment and ethic affairs, participants underwent answered a questionnaire about previous history data, and underwent physical examination with anthropometric data and specific tests for joint or muscle injuries in the lower limbs and warmed-up for 5 minutes on a stationary bicycle.

\section{Y Balance Test}

The Y Balance Test (YBT) evaluates the unipodal balance and the dynamic neuromuscular control of the lower limbs and is an adaptation of the Star Excursion Balance Test, where only the anterior, posteromedial and posterolateral components are evaluated. ${ }^{7}$ A Y-shaped figure demarcated on the floor with tape and the voluntee stands in its center. It is performed in the unipodal support, so that the volunteer aimes to keep a fixed foot on the ground in the center of the axis of a Y-shaped while trying to aim the most distal point in all three lines (anterior, postero-lateral and posteromedial) with the tip of the great toe of the other foot. After gently touching the floor, the subject must returned to the starting position without full discharge of body weight. ${ }^{14}$ Six repetitions are allowed for learning. Would the supporting foot be removed from the initial position or the non-fixed foot be supported to regain balance, the repetition was disregarded. The test was performed bilaterally, starting with the dominant limb as a fixed foot. Three repetitions were performed in each direction and the greatest distance reached by the volunteer was considered as the final score.

The actual limb length was measured for normalization of values, along with the range values obtained in the test, the mean and standard deviation for each direction were calculated. The range measurement is normalized for limb length to allow comparison between athletes. ${ }^{15}$ The normalized value is calculated by a formula consisting of the sum of the 3 range values divided by 3 times the limb length, multiplied by 100. Difference of $4 \mathrm{~cm}$ between dominant and non-dominant member is expected, but larges values are considered as risk of injury. ${ }^{15}$

\section{Dorsiflexion Lunge Test}

Dorsiflexion (DF) is important for many activities, from the simplest ones such as walking or climbing a step, to sports activities of impact like landing from a jump, a sprint or the stabilization of the foot of support during a kick. Athletes with restriction of dorsiflexion range of motion present an increased risk of injury. ${ }^{16}$ The Dorsiflexion Lunge Test (DLT) was performed with weight discharge, placing the anterior extremity of the foot perpendicularly in contact with the wall and the knee also supported 
on the wall. The volunteer was then asked to remove the foot from the wall by sliding it back so that the knee did not lose contact with the wall and the heel of the tested foot did not lose contact with the ground. Then the maximum distance between the anterior extremity of the foot and the wall was measured with tape measure. Distances shorter than 9 to 10 cm suggest DF restriction. This test is predictive of future soccer injuries. ${ }^{11}$

\section{Statistical Analisys}

Quantitative data were tested for normality and summarized in measures of central tendency and dispersion. Comparison between groups used Student's T-test.

YBT score was calculated and normalized by adding the 3 maximum reaches (anterior postelolateral and posteromedial) and divided by triple the length of the lower limb multiplied by 100. Data were plotted and compared between groups using T-student test.

The correlation between DLT and YBL tests was performed using Pearson's correlation test and expressed graphically using the graphical tool of Microsoft Excel software. To interpret the strength of the correlation measured by the $r$ coefficient, the values 1 and -1 signified a perfect, positive or negative correlation, respectively. The approximation of $r$ coefficient to 0 indicates progressively lower correlations.

\section{RESULTS}

Thirty-six amateur athletes and 60 professionals participated in this study. Both groups were similar in relation to weight, height, body mass index (BMI) and dominance of the lower limbs, but the professionals were older and the amateur athletes presented with a higher incidence of previous injuries when compared to the professional athletes (Table 1). One professional athlete was excluded from the survey because of a recent injury.

There was no significant difference in relation to the restriction of dorsiflexion of the ankle joint between dominant and non-dominant limbs evaluated by Dorsiflexion Lunge Test in amateur or professional athletes (Table 2).

There was no significant difference in relation to the unipodal balance and dynamic neuromuscular control of dominant and non-dominant lower limbs evaluated by the Y Balance Test of amateur athletes. However, there was a significant difference $(p<0.02)$ between dominant and non-dominant members of professional athletes with larger values in the non-dominant limb (Table 3).

There were weak correlations between the YBT and DLT either in the dominant and in non-dominant limbs of amateur and professional soccer athletes in the scatter plot when analyzed by Pearson's coefficient (Figures 1 and 2).

Table 1. Anthropometric data of professional and amateur soccer athletes

\begin{tabular}{c|c|c|c}
\hline \multirow{2}{*}{ Variable } & Professionals & Amateurs & \multirow{2}{*}{ P-value* } \\
\cline { 2 - 3 } & Mean \pm SD & Mean \pm SD & \\
\hline Age (years) & $28.5 \pm 4.5$ & $22.5 \pm 3.1$ & $0.01^{*}$ \\
\hline Weight $(\mathrm{Kg})$ & $78.6 \pm 8.1$ & $78.6 \pm 8.1$ & 0.44 \\
\hline Height $(\mathrm{m})$ & $1.8 \pm 0.1$ & $1.78 \pm 0.1$ & 0.18 \\
\hline BMl & $24.2 \pm 1.4$ & $24.7 \pm 2.4$ & 0.09 \\
\hline Dominance & $\mathrm{L}: 31 \% \mathrm{R}: 69 \%$ & $\mathrm{~L}: 22 \% \mathrm{R}: 88 \%$ & \\
\hline Previous injuries & $21 \%$ & $44 \%$ & \\
\hline
\end{tabular}

Legend: L: Left; A: Right; BMI: body mass index; DP- Standard Deviation; * Student's T test.

Table 2. Results of DLT analysis in amateur and professional athletes in dominant and non-dominant limbs. P> 0.05 .

\begin{tabular}{c|c|c|c}
\hline \multicolumn{4}{|c}{ Dorsiflexion Lunge Test $(\mathbf{c m})$} \\
\hline & Dominant & Non dominant & P-Value \\
\hline Profissionals & $9.9 \pm 3.7$ & $9.9 \pm 3.1$ & 0.44 \\
\hline Amateurs & $9.7 \pm 3.5$ & $9.9 \pm 3.7$ & 0.21 \\
\hline
\end{tabular}

Table 3. Results of the YBT analysis in dominant and non-dominant members of amateur athletes and soccer professionals. $P>0.05$.

\begin{tabular}{c|c|c|c}
\hline \multicolumn{4}{c}{ Y Balance Test } \\
\hline & Dominant & Non dominant & P-Value \\
\hline Profissionals & $90.2 \pm 8.7$ & $91.1 \pm 8.6$ & $0.02^{*}$ \\
\hline Amateurs & $90.6 \pm 8.3$ & $90.2 \pm 1.0$ & 0.28 \\
\hline
\end{tabular}

YBT X DLT Dominant amateurs and professionals

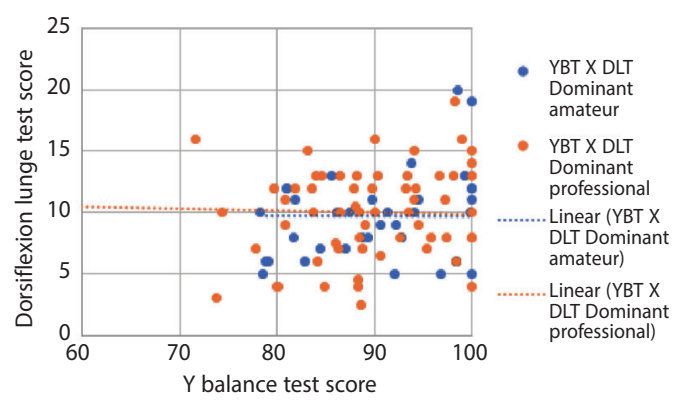

Figure 1. Graphical representation of the Pearson correlation test, correlating the DLT and YBT tests between amateur and professional soccer players in the dominant limb. Pearson Correlation: Professional Dom =0.16; Amateur Dom $=0.32$.

\section{YBT X DLT Non dominant amateurs and professionals}

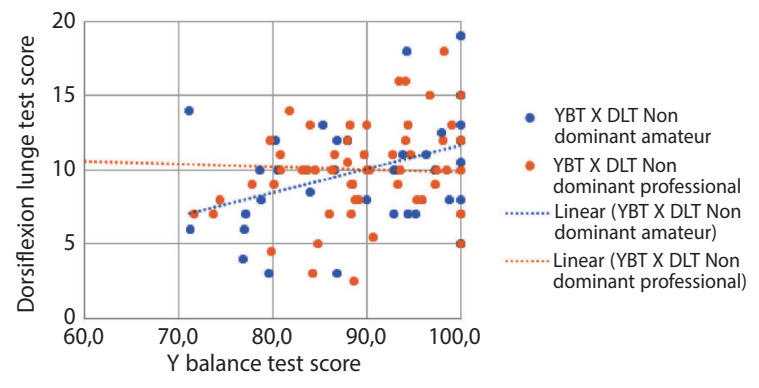

Figure 2. Graphical representation of the Pearson correlation test, correlating the DLT and YBL tests between amateur and professional soccer players in the non-dominant member. Pearson Correlation Professional Ndom =0.21; Amateur Ndom.

\section{DISCUSSION}

This study demonstrated no difference between amateur and professional soccer athletes in relation to the anthropometric data, but the amateur athletes presented a higher index of previous injury in relation to the other group. The presence of previous injuries is an important risk factor associated with the recurrence of ankle joint injuries ${ }^{13}$, allegedly caused by proprioceptive deficits, as well as damages in the mechanoreceptors located inside the skin, musculotendinous unit, bone, ligament and capsules, which collaborate to weakened perception of joint position. Impaired proprioception, altered neuromuscular control, muscle strength deficit, and decreased postural control may result in functional instability of the ankle joint .

Another important risk factor for common lower limb injuries is the decreased range of motion (ROM) of the ankle joint. ${ }^{17}$ Athletes with ankle ROM reduction are 5 times more likely to develop new lesions ${ }^{9}$, as well as to claim limitations in other daily activities. Risk of injuries is associated to dorsiflexion measures below the normal range of motion from $11.2^{\circ}$ and $25^{\circ}$ dorsiflexion. ${ }^{18}$ Clanton et al. considered joint mobility to be restricted when the angle of the tibial axis in relation to the wall was less than $35^{\circ}$, and the hallux-wall distance smaller than $9 \mathrm{~cm}$. Data from both studies support our findings and show that athletes with the previously mentioned characteristics will have worse performance in DLT. 
Knowing that postural control may also be impaired in these individuals, specific tools are indicated to evaluate this aspect. YBT evaluates proprioception, static and dynamic balance, and requires concomitant neuromuscular mobility and control. Higher values indicate better performance, better balance and proprioception.

This study demonstrated a statistically significant difference in YBT between dominant and non-dominant lower limbs in professional athletes but not in amateurs, which may result from differences in routine and intensity of training and games, as well as more intense physical preparation in professional athletes. In addition, with greater intensity of games and training, lower limb asymmetries may become more intense because specialized sport movements like support of body weight in the non-dominant limb and knee extension during kicking in the dominant limb.

Lower limbs asymmetries increase the risk of injury. ${ }^{19}$ The differences between limbs may occur in relation to flexibility, diameter, limb length and muscle strength. ${ }^{20}$ In sports such as soccer, the dominance of one of the lower limbs may increase the occurrence of injuries because it is preferentially used for kicking, pushing, jumping or landing. ${ }^{21}$

Regarding the results of the correlation between the two YBT and DLT functional tests, a low correlation was found between tests on the dominant lower limbs of professional $(r=0.16)$ and amateur athletes $(r=0.32)$. We also found a low correlation between tests on non-dominant lower limbs of professional $(r=0.21)$ and amateur athletes $(r=0.32)$. Hoch et al. ${ }^{12}$ showed that the DLT score shows is strongly correlated with the YBT anterior range score, although no correlation in the posterolateral and postero-medial scores could be demonstrated. A study by Basnett et al. ${ }^{10}$ also showed a positive correlation between DLT only with the YBT anterior range, indicating that it requires a greater range of dorsiflexion movement compared to the other directions. These authors also shows that the ability to use range of motion of the hip, knee and ankle has a strong relation to the range of the test range. While the ankle joint is more related to the anterior range, the hip and knee joints are related to the 3 directions of the test. Diverging from findings found in other studies, our study showed a low correlation between YBT and DLT in dominant and non-dominant lower limbs of amateur athletes and soccer professionals. Our study however used the composite score in YBT as a result, obtaining a value referring to the three ranges concomitantly. Also, because athletes had very similar functioning profiles and represent the vast majority of the sample, the different levels of range of motion (DLT) and motor control (YBT) which would favor a clearer and stronger correlation between these functional tests were not observed. All the evaluated individuals obtained high scores in both evaluations, thus it would be more difficult to obtain a correlation. Had the sample subjects with more varied ranges of motion of lower performance in YBT, a clearer correlation might be identified. Even though, small correlation values indicate that, although there are biomechanical relationships between the range of motion of the ankle joint and the postural control, proprioception and static and dynamic balance, the tests may be used independently and should be both used in clinical practice in pre-season assessment.

Moreover, besides knowing the correct recommendations to perform the tests, the professional must be aware of the musculoskeletal deficits that are determinant for the risk of injuries. Also he must be familiar with the incidence and characteristics of the injuries reported in soccer, ${ }^{9}$ so the decision on which functional tests are most suitable for the evaluation of the athletes will have more support.

The limitations of this study refer to the number of volunteers, especially among amateur athletes, leading to a significant difference in the number of participants in each group ( $\mathrm{n}=36$ for amateur athletes and $n=71$ for professional athletes). This difference in the size of the groups may be due to the lack of understanding on the part of amateur athletes of the importance of performing functional tests in sports practice. Also, professional clubs were more motivated to realize the complete evaluation of the athletes in the pre-season period. Amateur athletes had very little control of their physical challenges and are no as careful with their health as professionals, which may have further biased the comparison. Future studies should investigate the relationship between functional tests in athletes and consider the difference between the populations analyzed.

\section{CONCLUSION}

The low relationship between YBT and DLT in amateur and professional athletes indicates that both tests should be performed to obtain a broader assessment of athletes' musculoskeletal and functional characteristics so that deficits are identified and corrected more effectively.

All authors declare no potential conflict of interest related to this article

AUTHORS' CONTRIBUTIONS: Each author made significant individual contributions to this manuscript. LSM (0000-0002-4723-6235): writing, review and data collection; MGX (0000-0002-1837-8226): writing and data collection; MR (0000-0001-9549-8830); review, writing, and mentoring.. *ORCID (Open Researcher and Contributor ID).

\section{REFERÊNCIAS}

1. Gabbe BJ, Finch CF, Wajswelner H, Bennell KL. Predictors of lower extremity injuries at the community level of Australian football. Clin J Sport Med. 2004;14(2):56-63.

2. Carazzato JG. Lesões atléticas. Manual de medicina do esporte da sociedade brasileira de medicina esportiva .1994;2:17-31

3. Ribeiro RN, Vilaça F, Oliveira HU, Vieira LS. Prevalência de lesões no futebol em atletas jovens: estudo comparativo entre diferentes categorias. Ver Bras Educ Fís Esp. 2007;21(3);189-94.

4. Vaes P, Duquet W, Van Gheluwe B. Peroneal reaction times and eversion motor response in healthy and unstable ankles. J Athl Train. 2002;37(4):475-80.

5. Konradsen L. Factors contributing to chronic ankle instability: kinaesthesia and joint position sense. J Athl Train. 2002;37(4):381-85.

6. Kaminski TW, Hartsell HD. Factors contributing to chronic ankle instability: A strength perspective. J Athl Train. 2002;37(4):394-405.

7. Pope R, Herbert R, Kirwan J. Effects of ankle dorsiflexion range and pre-exercise calf muscle stretching on injury risk in Army recruits. Aust J Physiother. 1998:44(3):165-72.

8. Nichols DS, Glenn TM, Hutchinson KJ. Changes in the mean center of balance during balance testing in young adults. Phys Ther. 1995;75(8):699-706.

9. Bird SP, Markwick WJ. Musculoskeletal screening and functional testing: considerations for basketball athletes. Int J Sports Phys Ther. 2016;11(5):784-802.

10. Basnett CR, Hanish MJ, Wheeler TJ, Miriovsky DJ, Danielson EL, Barr JB, et al. Ankle dorsiflexion range of motion influences dynamic balance in individuals with chronic ankle instability. Int J Sports Phys Ther. 2013;8(2):121-8.

11. Clanton TO, Matheny LM, Jarvis HC, Jeronimus AB. Return to Play in Athletes Following Ankle Injuries. Sports Health. 2012;4(6):471-4.
12. Hoch MC, Staton GS, Medina McKeon JM, Mattacola CG, McKeon PO. Dorsiflexion and dynamic postural control deficits are present in those with chronic ankle instability. J Sci Med Sport. 2012;15(6):574-9.

13. Plisky PJ, Rauh MJ, Kaminski TW, Underwood FB. Star Excursion Balance Test as a predictor of lower extremity injury in high school basketball players. J Orthop Sports Phys Ther. 2006;36(12):911-9.

14. Imai A, Kaneoka K, Okubo Y, Shiraki H. Comparison of the immediate effect of different types of trunk exercise on the star excursion balance test in male adolescent soccer players. Int J Sports Phys Ther. 2014;9(4):428-35.

15. Gonell AC, Romero JA, Soler LM. Relationship between the y balance test scores and soft tissue injury incidence in a soccer team. Int J Sports Phys Ther. 2015;10(7):955-66.

16. Vincenzino B, Prangley I, Martin D. The initial effect of two Mulligan mobilization with movement treatment techniques on ankle dorsiflexion. In: Proceedings of the Australian Conference of Science and Medicine in Sport, Perth, WA; June 2001.

17. Powden CJ, Hoch JM, Hoch MC. Reliability and minimal detectable change of the weight-bearing lunge test: A systematic review. Man Ther. 2015;20(4):524-32.

18. Moseley AM, Crosbie J, Adams R. High- and low-ankle flexibility and motor task performance. Gait Posture. 2003;18(2):73-80

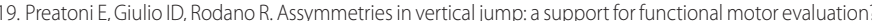
The 3rd European Medical and Biological Engineering Conference. Prague, Czech Republic; 2005. p. 20-5.

20. Witvrouw E, Danneels L, Asselman P, D'Have T, Cambier D. Muscle flexibility as a risk factor for developing muscle injuries in male professional soccer players. A prospective study. Am J Sports Med. 2003;31(1):41-6.

21. Murphy DF, Connolly DA, Beynnon BD. Risk factors for lower extremity injury: a review of the literature. Br J Sports Med. 2003;37(1):13-29. 